\title{
SYNTHESIS OF ALUMINIUM BORATE WHISKERS THROUGH WET MOLTEN SALT METHOD
}

\author{
XUE ZHANG, ${ }^{\#}$ ZHAOYANG LIU, YUTING ZHOU, JINGKUN YU \\ School of Metallurgy, Northeastern University, Shenyang 110819, P.R. China \\ "E-mail: zhaoyangliu@stumail.neu.edu.cn
}

Submitted September 18, 2017; accepted November 20, 2017

\begin{abstract}
Keywords: High temperature molten salt, Aluminum borate, Whisker material
Aluminium borate $\left(\mathrm{Al}_{4} \mathrm{~B}_{2} \mathrm{O}_{9}\right)$ whiskers were successfully synthesized by the wet molten salt method at $800^{\circ} \mathrm{C}$ through control the aluminum/boron atomic ratio and synthesis temperature. The as-received $\mathrm{Al}_{4} \mathrm{~B}_{2} \mathrm{O}_{9}$ whiskers were characterized by scanning electron microscopy (SEM), X-ray diffraction (XRD) and thermal analysis. A solution-liquid-solid (SLS) mechanism was proposed for the growth mechanism of the whiskers on the basis of the experimental phenomena and the TG-DSC data of the mixed raw materials.
\end{abstract}

\section{INTRODUCTION}

Borate whiskers as one of the one-dimensional nanostructure materials have received extensive attention due to their interesting mechanical, electrical and optical properties [1-5]. Among them, aluminum borate $\left(\mathrm{Al}_{4} \mathrm{~B}_{2} \mathrm{O}_{9}\right)$ whiskers are excellent and cheap one-dimensional ceramic materials due to the unique physical properties and widely potential applications as compared with bulk materials. In addition, aluminum borate whiskers are a kind of nonpoisonous, harmless and pollution-free natural product. Because of its excellent properties and broad application prospects, some synthesis methods have been developed such as thermal evaporation [6], sol-gel [7-8], chemical vapor deposition [9] and high temperature molten salt method [10]. For example, Elssfah et al. [11] obtained singlecrystalline $\mathrm{Al}_{4} \mathrm{~B}_{2} \mathrm{O}_{9}$ nanowires by a direct calcination of $\mathrm{Na}_{2} \mathrm{~B}_{4} \mathrm{O}_{7} \cdot 10 \mathrm{H}_{2} \mathrm{O}$ and $\mathrm{Al}\left(\mathrm{NO}_{3}\right)_{3} \cdot 9 \mathrm{H}_{2} \mathrm{O}$ at $850^{\circ} \mathrm{C}$, but the borax is toxic and not conductive to environmental. Tao et al. [12] obtained single-crystalline $\mathrm{Al}_{4} \mathrm{~B}_{2} \mathrm{O}_{9}$ nanowires by a one-step combustion method at $900^{\circ} \mathrm{C}$, but the synthesis temperature is a little high.

Among these methods, the high temperature molten salt method could be considered as a simple way, however, high temperature molten salt method belongs to solid reaction, it requires relatively high calcination temperature in the synthesis process, at the same time, it could cause inhomogeneous products easily, and the reaction cycle is too long to application.
In this paper, we report a simple route to synthesize the $\mathrm{Al}_{4} \mathrm{~B}_{2} \mathrm{O}_{9}$ whiskers without using any metal-catalyst at the low temperature of $800^{\circ} \mathrm{C}$, we used the liquid phase method replace the solid phase method, and the reaction efficiency could be greatly increased.

\section{EXPERIMENTAL}

\section{Raw materials}

The raw materials used in this study were boric acid $\left(\mathrm{H}_{3} \mathrm{BO}_{3}\right)$, aluminum chloride hexahydrate $\left(\mathrm{AlCl}_{3} \cdot 6 \mathrm{H}_{2} \mathrm{O}\right)$, sodium hydroxide $(\mathrm{NaOH})$ and sodium chloride $(\mathrm{NaCl})$. All materials were analytically reagents grade.

\section{Synthesis and analysis}

Appropriate amount of $\mathrm{H}_{3} \mathrm{BO}_{3}$ and $\mathrm{NaCl}$ were weighted and dissolved with $400 \mathrm{ml}$ distilled water, and then different amount of $\mathrm{AlCl}_{3} \cdot 6 \mathrm{H}_{2} \mathrm{O}$ was added into the above solution and kept the molar ratio between $\mathrm{H}_{3} \mathrm{BO}_{3}$ and $\mathrm{AlCl}_{3}$ at $1,1.5$ and 2, respectively. When they totally dissolved, $\mathrm{NaOH}$ was added with continuous strong stirring $(500 \mathrm{r} / \mathrm{min})$ by electromagnetic stirrer, and a large amount of white precipitate was obtained. In the reaction process, the temperature of solution was kept at $80^{\circ} \mathrm{C}$ by super thermostatic water bath and the range kept in $\pm 1^{\circ} \mathrm{C}$. After $2 \mathrm{~h}$ for reaction, the above precipitate was calcined at a certain temperature $\left(600,800,1000^{\circ} \mathrm{C}\right)$ for $2 \mathrm{~h}$ in the air, and then washed by ethyl alcohol and dried at $120^{\circ} \mathrm{C}$ for $12 \mathrm{~h}$. The process flow chart as follows. 


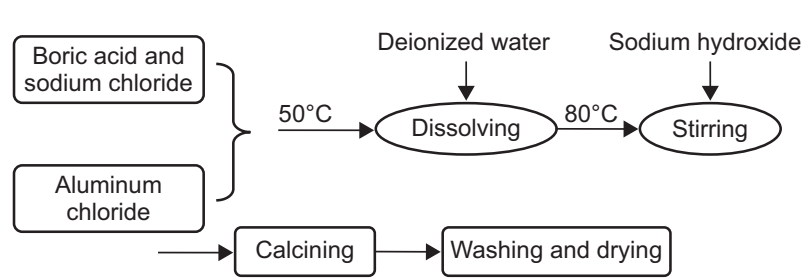

Figure 1. Process flow chart for preparing aluminium borate $\left(\mathrm{Al}_{4} \mathrm{~B}_{2} \mathrm{O}_{9}\right)$ whiskers.

The phase compositions of obtained powders were determined with X-ray powder diffraction (XRD). The diffraction patterns were recorded on a Philips PW3040/60 X-ray diffractometer using a $\mathrm{Cu} \mathrm{K} \alpha(\lambda=$ $=0.154056 \mathrm{~nm}$ ) radiation source. The XRD scans were made from $5^{\circ}$ to $80^{\circ}$ in $2 \theta$ with a step rate was $5^{\circ}$ per minute. The morphologies of the obtanied precipitation and $\mathrm{Al}_{4} \mathrm{~B}_{2} \mathrm{O}_{9}$ were observed with field emission scanning electron microscopy (FE-SEM, Zeiss-ultra plus), and the changes in mass and exothermic absorption in the heating were investigated by the thermogravimetric analysis and differential scanning calorimetry (TG-DSC).

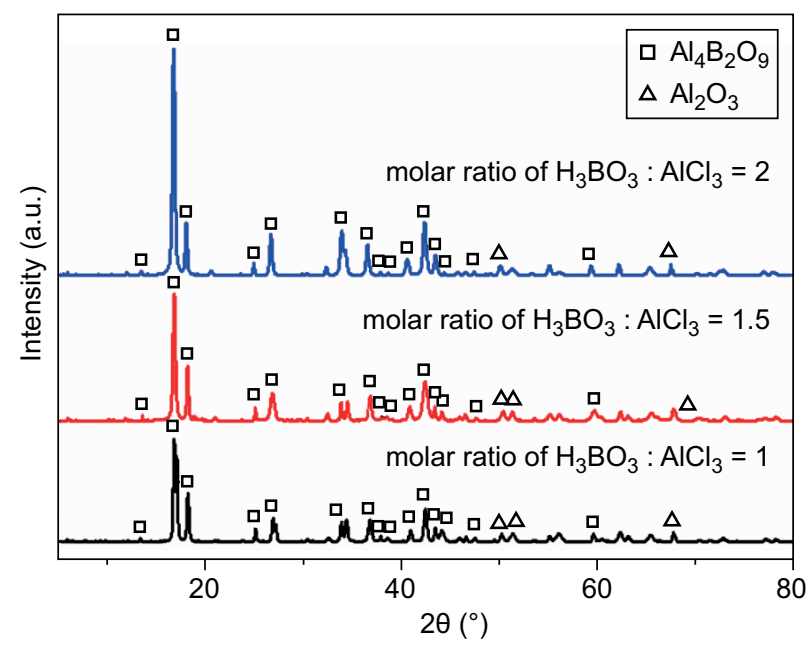

a) XRD patterns

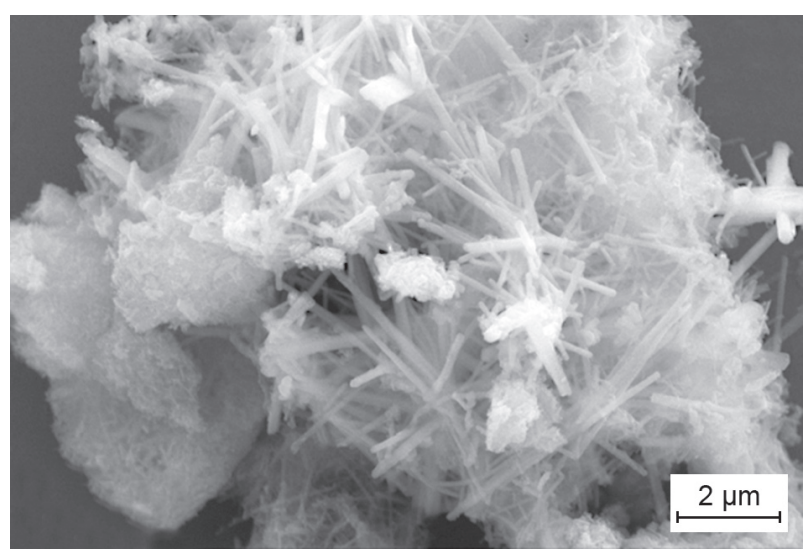

c) molar ratio $1.5: 1$

\section{RESULTS AND DISCUSSION}

Figure 2 shows the XRD patterns and the SEM micrographs of the samples obtained by calcining the precipitate at $800^{\circ} \mathrm{C}$ for $2 \mathrm{~h}$, and the molar ratio of $\mathrm{H}_{3} \mathrm{BO}_{3} / \mathrm{AlCl}_{3}$ is $1,1.5$ and 2, respectively. It is easily to see from those XRD patterns (Figure 2a), $\mathrm{Al}_{4} \mathrm{~B}_{2} \mathrm{O}_{9}$ is the main phase, and a very small amount of $\mathrm{Al}_{2} \mathrm{O}_{3}$ also could be observed. At the same time, it could be seen that the crystallinity of the $\mathrm{Al}_{4} \mathrm{~B}_{2} \mathrm{O}_{9}$ phase increased with the increasing of the amount of boric acid addition. When the molar ratio of $\mathrm{H}_{3} \mathrm{BO}_{3} / \mathrm{AlCl}_{3}$ was 2 , the intensity of the diffraction peak was strongest; it means that the crystallization of the phase was best. The fitting crystalline parameters are $a=1.47460 \mathrm{~nm}, b=1.52680 \mathrm{~nm}$ and $c=0.55570 \mathrm{~nm}, \alpha=\beta=\gamma=90^{\circ}$ (reference code: 00-0290010). It could be understood from the SEM micrographs that the molar ratio of $\mathrm{H}_{3} \mathrm{BO}_{3} / \mathrm{AlCl}_{3}$ made a difference in $\mathrm{Al}_{4} \mathrm{~B}_{2} \mathrm{O}_{9}$ whiskers morphology (Figures 2b-d). When the molar ratio of $\mathrm{H}_{3} \mathrm{BO}_{3} / \mathrm{AlCl}_{3}$ was 1 , the whiskers showed a shorter and thicker shape, and the growth of the whiskers seemed to be messy and wide range of sizes (see Figure 2b). When the molar ratio increased to 1.5, uniform $\mathrm{Al}_{4} \mathrm{~B}_{2} \mathrm{O}_{9}$ whiskers have obtained with which the length-diameter ratio of 15 (see Figure 2c). However, it

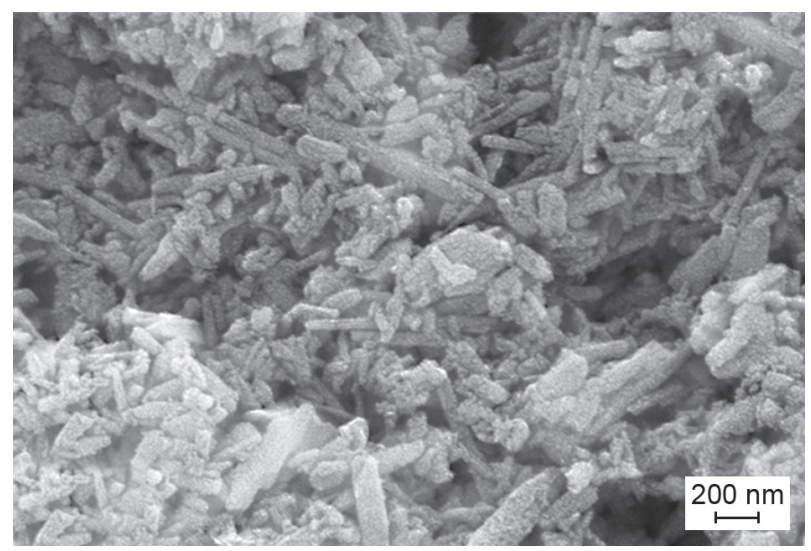

b) molar ratio $1: 1$

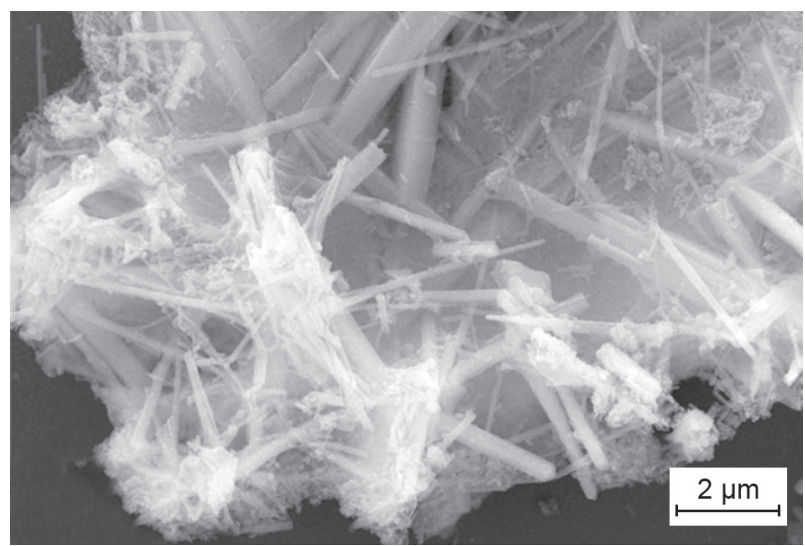

d) molar ratio 2:1

Figure 2. XRD patterns (a) and SEM micrographs of samples obtained by various $\mathrm{H}_{3} \mathrm{BO}_{3} / \mathrm{AlCl}_{3}$ molar ratio: b) $1: 1$, c) $1.5: 1$ and d) $2: 1$. 
is worth to note that, the $\mathrm{Al}_{4} \mathrm{~B}_{2} \mathrm{O}_{9}$ whiskers not became more tenuous further but coarse when the molar ratio increased to 2, and the length-diameter ratio decreased to 10 , the main reason might be that the excess of boron oxide increased the resistance of alumina movement, and alumina accumulated in the radial region of the whiskers,

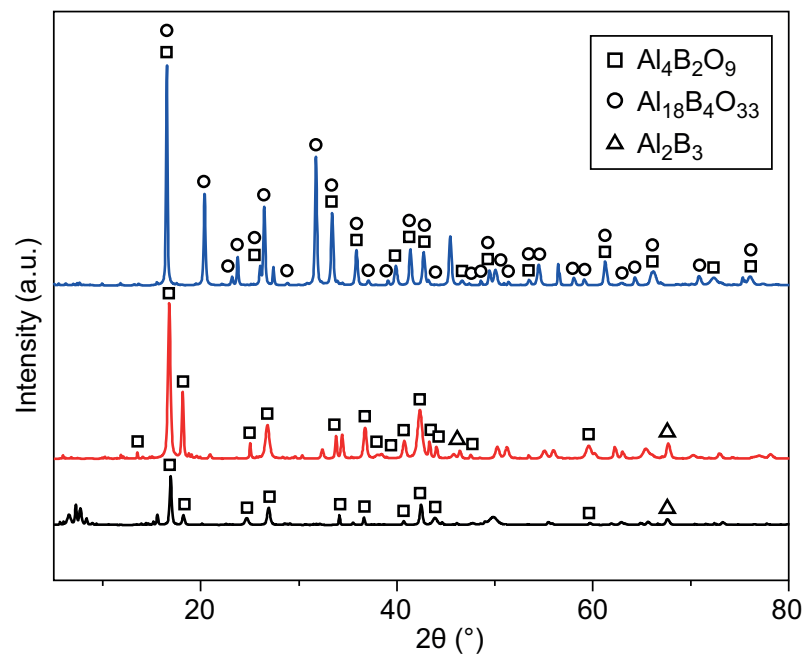

Figure 3. XRD patterns of samples obtained by calcning the precipitate at different temperature.

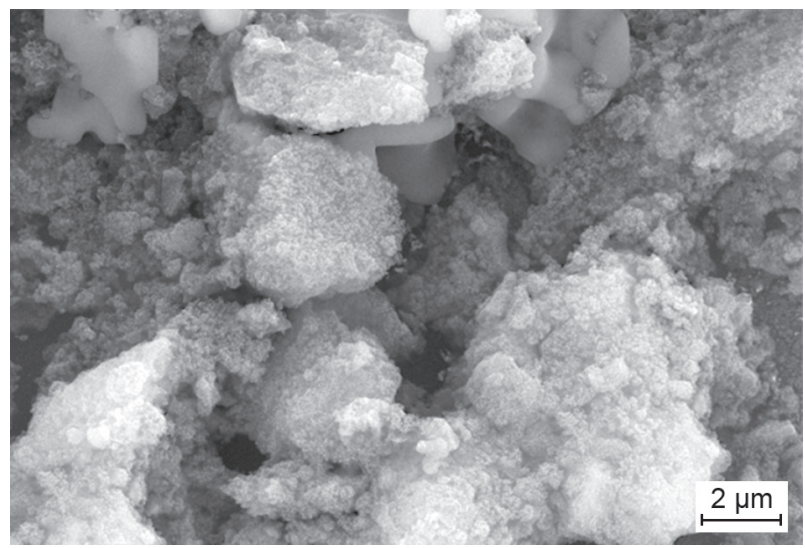

a) precipitate

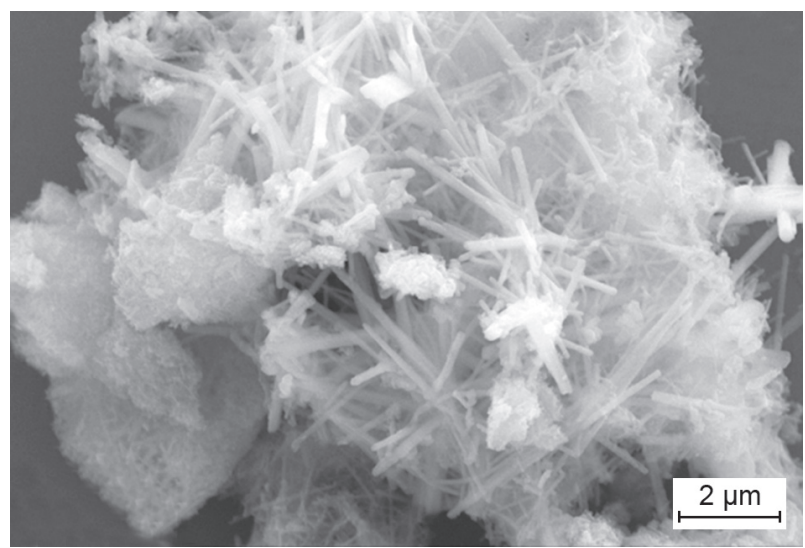

c) $800^{\circ} \mathrm{C}$ which resulted in radial growth and effected the lengthdiameter radio of the whiskers. It means that the growth of $\mathrm{Al}_{4} \mathrm{~B}_{2} \mathrm{O}_{9}$ whiskers was strictly restrained by the molar ratio of $\mathrm{H}_{3} \mathrm{BO}_{3} / \mathrm{AlCl}_{3}$. Compared with the above SEM micrographs, the molar ratio of 1.5 was considered as a suitable for the growing of the whiskers.

Figure 3 shows XRD patterns of the samples obtained by calcining the precipitate at various heating temperature for $2 \mathrm{~h}$, prepared with the molar ratio of $\mathrm{H}_{3} \mathrm{BO}_{3} / \mathrm{AlCl}_{3}$ is 1.5 . Form the Figure 3, it could be seen that the crystallinity of the whiskers became strong with the increasing of the heating temperature. At the same time, the heating temperature also affected the phase composition. When the heating temperature increased to $1000^{\circ} \mathrm{C}$, besides the $\mathrm{Al}_{4} \mathrm{~B}_{2} \mathrm{O}_{9}$ phase, $\mathrm{Al}_{18} \mathrm{~B}_{4} \mathrm{O}_{33}$ was also formed. At this point, the product was not a single phase. The Figure $3 \mathrm{a}$ and $\mathrm{b}$ patterns can be indexed as orthorhombic $\mathrm{Al}_{4} \mathrm{~B}_{2} \mathrm{O}_{9}$. The fitting crystalline parameters are $a=1.47460 \mathrm{~nm}, b=1.52680 \mathrm{~nm}$ and $c=0.55570 \mathrm{~nm}$, $\alpha=\beta=\gamma=90^{\circ}$ (reference code: 00-029-0010). For pattern (c), $\mathrm{Al}_{18} \mathrm{~B}_{4} \mathrm{O}_{33}$ phase is also orthorhombic, the fitting crystalline parameters are $a=0.76874 \mathrm{~nm}, b=1.50127$ $\mathrm{nm}$ and $c=0.56643 \mathrm{~nm}, \alpha=\beta=\gamma=90^{\circ}$ (reference code: 00-032-0003).

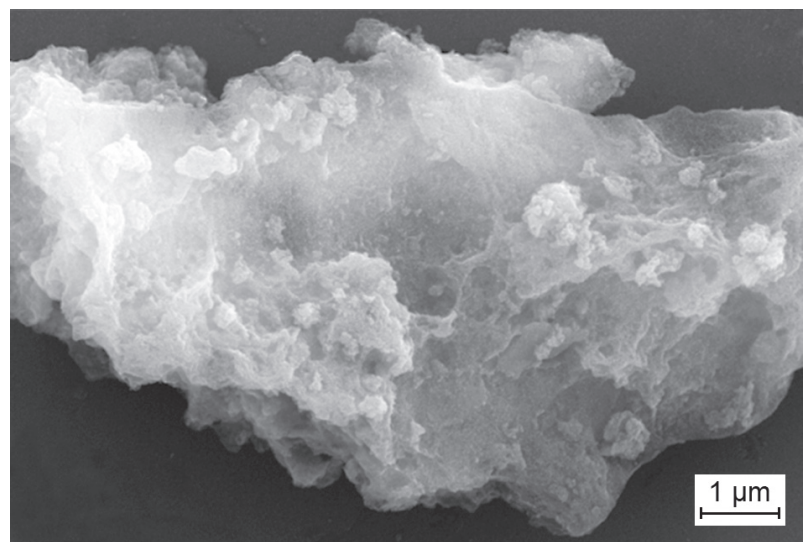

b) $600^{\circ} \mathrm{C}$

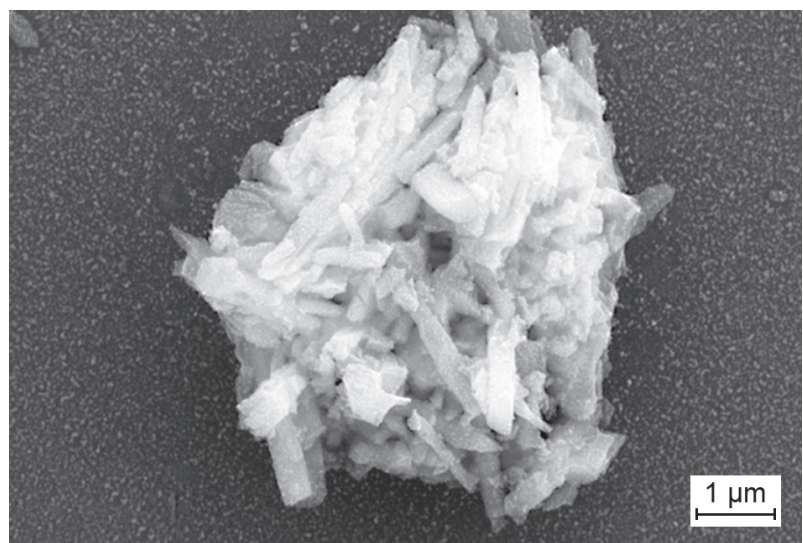

d) $1000^{\circ} \mathrm{C}$

Figure 4. SEM micrographs of the precipitate and samples obtained at various heating temperature: a) precipitate, b) $600^{\circ} \mathrm{C}$, c) $800^{\circ} \mathrm{C}$ and d) $1000^{\circ} \mathrm{C}$. 
Figure 4 shows the SEM micrographs of the precipitate and samples obtained by heating the precipitate at various heating temperature for $2 \mathrm{~h}$. The morphology of the samples was influenced by the heating temperature obviously. The whiskers were not found in the precipitate (see the Figure $4 \mathrm{a}$ ) and the samples obtained by heating the precipitate at $600^{\circ} \mathrm{C}$ for $2 \mathrm{~h}$ (Figure $4 \mathrm{~b}$ ). However, it was formed when the heating temperature increased to $800^{\circ} \mathrm{C}$ (see the Figure $4 \mathrm{c}$ ). The whiskers were very straight with diameter ranging from 100 to $200 \mathrm{~nm}$ and about $2 \mu \mathrm{m}$ at length when heated at $800^{\circ} \mathrm{C}$. However, it became shorter when the heating temperature raised to $1000^{\circ} \mathrm{C}$.

From the above analysis we know that the diameter of whiskers increased with the increasing of temperature after reaching a certain temperature. The reason for this phenomenon is that at a high temperature, the vapor pressure of the product was large, and the probability of collisions between atoms was high, so the initial crystal nucleus grown easily, and when it began to grow subsequently, the size of the crystal nucleus was so large that the diameter of the whiskers increased [13].

According to the previous research results, the minimum temperature for forming the $\mathrm{Al}_{4} \mathrm{~B}_{2} \mathrm{O}_{9}$ whiskers was about $780^{\circ} \mathrm{C}$ [12], and in the case of using the tradition method, the heating temperature was about $900^{\circ} \mathrm{C}$ [12] or even $1000^{\circ} \mathrm{C}$ [14]. However, it was decreased to $800^{\circ} \mathrm{C}$ by using the wet molten salt method in this study, which was largely saved the energy.

Figure 5 shows the differential scanning calorimeter (DSC) and Thermogravimetry (TG) curves of the precipitate by the blue and the red line, respectively. There are two endothermic peaks and one exothermic peak on the DSC curves, corresponding to the temperature of $114.3^{\circ} \mathrm{C} 270.3^{\circ} \mathrm{C}$ and $798.8^{\circ} \mathrm{C}$, respectively. The endothermic peaks were attributed to the interlayer water removing of $\mathrm{H}_{3} \mathrm{BO}_{3}$ and $\mathrm{Al}(\mathrm{OH})_{3}$ decomposing, and the corresponding reaction equations were as follow:

$$
\begin{gathered}
2 \mathrm{H}_{3} \mathrm{BO}_{3}(\mathrm{~s}) \rightarrow \mathrm{B}_{2} \mathrm{O}_{3}(\mathrm{~s})+3 \mathrm{H}_{2} \mathrm{O}(\mathrm{l}) \\
2 \mathrm{Al}(\mathrm{OH})_{3}(\mathrm{~s}) \rightarrow \mathrm{Al}_{2} \mathrm{O}_{3}(\mathrm{~s})+3 \mathrm{H}_{2} \mathrm{O}(\mathrm{l})
\end{gathered}
$$

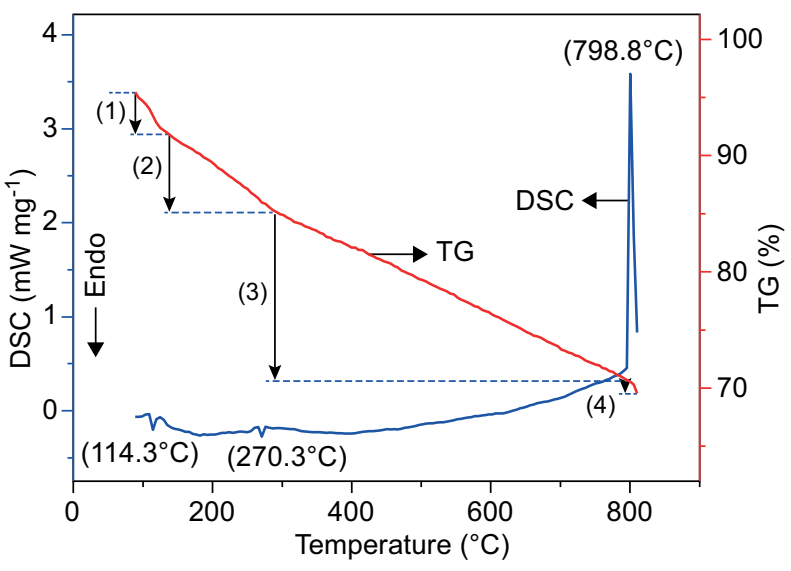

Figure 5. DSC and TG curves of the precipitate.
On the other hand, the exothermic peak at $798.8^{\circ} \mathrm{C}$ was attributed to the reaction between $\mathrm{B}_{2} \mathrm{O}_{3}$ and $\mathrm{Al}_{2} \mathrm{O}_{3}$, and the reaction equation was as follow:

$$
2 \mathrm{Al}_{2} \mathrm{O}_{3}(\mathrm{~s})+\mathrm{B}_{2} \mathrm{O}_{3}(\mathrm{l}) \rightarrow \mathrm{Al}_{4} \mathrm{~B}_{2} \mathrm{O}_{9}(\mathrm{l})
$$

In the process of whiskers growth, it is a key issue to induce $1 \mathrm{D}$ crystal growth in a controlled manner. At this point, many methods have been developed, such as the metal-catalyst-assisted vapor-liquid-solid (VLS) mechanism [15], the vapor-solid (VS) mechanism, and the template-assisted (TA) mechanism. Among these, the VLS mechanism is the most extensively used due to its simplicity and versatility. However, no metal-catalyst or templates were used in this study, and no tips were found at the end of the whiskers, which were considered as the mark of the VLS mechanism [16-18]. Thus, the VLS mechanism was not considered to be applied to the growth of as-prepared $\mathrm{Al}_{4} \mathrm{~B}_{2} \mathrm{O}_{9}$ whiskers.

According to the SEM micrographs and thermal analysis stated above, the formation of $\mathrm{Al}_{4} \mathrm{~B}_{2} \mathrm{O}_{9}$ could be divided into two parts in this study. The first part was the decomposition process of the initial reaction material, and the second part was that the formation and growth of whiskers nucleation. Therefore, we believe that the solution-liquid-solid (SLS) mechanism [19] is responsible for the whiskers' growth. The SLS mechanism is also called dissolution-precipitation mechanism, it means that the raw material was dissolved first and then decomposed into oxides, and then combined to form the target product, finally separated out after reaching saturation. The $\mathrm{Al}_{4} \mathrm{~B}_{2} \mathrm{O}_{9}$ whiskers were synthesized by heating the precipitate in air conditions. With the temperature increasing, $\mathrm{H}_{3} \mathrm{BO}_{3}$ first decomposed into $\mathrm{B}_{2} \mathrm{O}_{3}$ at about $250^{\circ} \mathrm{C}$, and then melted at about $450^{\circ} \mathrm{C}$ according to phase diagram [20]. The starting liquid droplet acted a catalyst as called self-catalysts [21]. The liquid droplet might continuously dissolve the Al-contained constituent to form the Al-B-O cluster with the aid of the cosolvent. When the liquid droplets became saturate, $\mathrm{Al}_{4} \mathrm{~B}_{2} \mathrm{O}_{9}$ crystals would begin to grow from the droplets. After continuous dissolved, and the formation of the nanoscale droplets and the $\mathrm{Al}_{4} \mathrm{~B}_{2} \mathrm{O}_{9}$ crystallized at the temperature lower than its melting point, providing the necessary conditions demanded by the SLS growth mechanism.

\section{CONCLUSIONS}

In conclusion, $\mathrm{Al}_{4} \mathrm{~B}_{2} \mathrm{O}_{9}$ whiskers were synthesized by a wet molten salt method at different ratio of $\mathrm{H}_{3} \mathrm{BO}_{3} /$ $\mathrm{AlCl}_{3}$ and calcined temperature for the first time. XRD and SEM analysis showed that the length-diameter ratio of the whiskers was desired when the $\mathrm{H}_{3} \mathrm{BO}_{3} / \mathrm{AlCl}_{3}$ atomic ratio is 1.5 and calcined temperature is $800^{\circ} \mathrm{C}$. At the same time, a solution-liquid-solid (SLS) mechanism was proposed for the growth mechanism of the whiskers. 


\section{REFERENCES}

1. Dai H., Wong E. W., Lu Y. Z., Fan S., Lieber C. M. (1995): Synthesis and characterization of carbide nanorods. Nature, 375(6534), 769-772. doi:10.1038/375769a0

2. Yang P., Lieber C.M. (1996): Nanorod-superconductor materials with composites: a pathway critical current high densities. Science, 273 (5283): 1836-184. doi:10.1126/ science. 273.5283 .1836

3. Lan B., Sun M., Lin T., Cheng G., Yu L., Peng S., Xu J. (2014): Ultra-long $\alpha-\mathrm{MnO}_{2}$ nanowires: control synthesis and its absorption activity. Materials Letters, 121, 234-237. doi:10.1016/j.matlet.2014.01.055

4. Cheng C., Ding X. X., Shi F. J., Cheng Y., Huang X. T., Qi S. R., Tang C. (2004): Preparation of aluminum borate nanowires. Journal of Crystal Growth, 263(1), 600-604. doi:10.1016/j.jcrysgro.2003.11.052

5. Peng L. M., Li X. K., Li H., Wang J. H., Gong M. (2006): Synthesis and microstructural characterization of aluminum borate whiskers. Ceramics International, 32(4), 365-368. doi: 10.1016/j.ceramint.2005.03.013

6. Ma R., Bando Y., Sato T., Golberg D., Zhu H., Xu C., Wu D. (2002): Synthesis of boron nitride nanofibers and measurement of their hydrogen uptake capacity. Applied Physics Letters, 81(27), 5225-5227. doi: 10.1063/1.1534415

7. Tang C. C., Elssfah E. M., Zhang J., Chen D. F. (2006): Morphology-and composition-controlled synthesis of aluminium borate nanowires without catalysts. Nanotechnology, 17(9), 2362. doi: 10.1088/0957-4484/17/9/047

8. Gupta R. K., Al-Ghamdi A. A., Al-Hartomy O. A., Al-Hazmi F., El-Tantawy F., Yakuphanoglu F. (2012): Synthesis and characterization of nanostructured aluminum borate by sol-gel method. Journal of Sol-gel Science and Technology, 64(1), 100-103. doi: 10.1007/s10971-012-2833-4

9. Li Y., Chang R. P. (2006). Synthesis and characterization of aluminum borate $\left(\mathrm{Al}_{18} \mathrm{~B}_{4} \mathrm{O}_{33}, \mathrm{Al}_{4} \mathrm{~B}_{2} \mathrm{O}_{9}\right)$ nanowires and nanotubes. Materials Chemistry and Physics, 97(1), 23-30. doi: 10.1016/j.matchemphys.2005.06.023

10. Wada H., Sakane K., Kitamura T., Hata H., Kambara H. (1991): Synthesis of aluminium borate whiskers in potassium sulphate flux. Journal of Materials Science Letters, 10(18), 1076-1077. doi: 10.1007/BF00720129
11. Elssfah E. M., Tang C. C., Zhang J., Song H. S., Ding X. X., Qi S. R. (2007): Low-temperature performance of $\mathrm{Al}_{4} \mathrm{~B}_{2} \mathrm{O}_{9}$ nanowires. Materials Research Bulletin, 42(3), 482-486. doi: 10.1016/j.materresbull.2006.06.021

12. Tao X., Wang X., Li X. (2007): Nanomechanical characterization of one-step combustion-synthesized $\mathrm{Al}_{4} \mathrm{~B}_{2} \mathrm{O}_{9}$ and $\mathrm{Al}_{18} \mathrm{~B}_{4} \mathrm{O}_{33}$ nanowires. Nano Letters, $7(10), 3172-3176$. doi: 10.1021/n1071772x

13. Peng H. Y., Pan Z. W., Xu L., Fan X. H., Wang N., Lee C. S., Lee S. T. (2001): Temperature dependence of Si nanowire morphology. Advanced Materials, 13(5), 317-320. doi: $10.1002 / 1521-4095(200103) 13: 5<317::$ AID-ADMA 317>3.0.CO;2-L

14. Peng S., Jinwen H., Wenwei W., Xuehang W. (2013): Preparation of aluminum borate whiskers by the molten salt synthesis method. Ceramics International, 39(6), 7263-7267. doi: 10.1016/j.ceramint.2013.02.007

15. Morales A. M., Lieber C. M. (1998): A laser ablation method for the synthesis of crystalline semiconductor nanowires. Science, 279(5348), 208-211. doi: 10.1126/science. 279.5348.208

16. Wang J., Sha J., Yang Q., Wang Y., Yang D. (2005): Synthesis of aluminium borate nanowires by sol-gel method. Materials Research Bulletin, 40(9), 1551-1557. doi: 10.1016/j.materresbull.2005.04.016

17. Wagner R. S., Ellis W. C. (1964): Vapor-liquid-solid mechanism of single crystal growth. Applied Physics Letters, 4(5), 89-90. doi: 10.1063/1.1753975

18. Duan X., Wang J., Lieber C. M. (2000): Synthesis and optical properties of gallium arsenide nanowires. Applied Physics Letters, 76(9), 1116-1118. doi: 10.1063/1.125956

19. Wang, F., Dong, A., Sun, J., Tang, R., Yu, H., \& Buhro, W. E. (2006). Solution- liquid- solid growth of semiconductor nanowires. Inorganic chemistry, 45(19), 7511-7521. doi: 10.1021/ic060498r

20. Readey M. J. (1992): Formation and sintering characteristics of aluminum borate whiskers. Journal of the American Ceramic Society, 75(12), 3452-3456. doi: 10.1111/j.11512916.1992.tb04448.x

21. Liu Y., Li Q., Fan S. (2003): Self-catalytic growth of aluminum borate nanowires. Chemical Physics Letters, 375(5), 632-635. doi:10.1016/S0009-2614(03)00930-8 